\title{
Alley Cropped Gliricidia sepium (Jacq.) Kunth ex. Walp. Enhance Soil Fertility and Yields of Cotton, Maize and Sorghum in Mali
}

\author{
Salif Doumbia ${ }^{1,}$, Sidiki Gabriel Dembele ${ }^{2}$, Fagaye Sissoko ${ }^{1}$, Odiaba Samake ${ }^{1}$, Fernando Sousa ${ }^{3}$, Cicek \\ Harun $^{3}$, Noah Adamtey ${ }^{3}$, Andreas Fliessbach ${ }^{3}$ \\ ${ }^{1}$ Institut d’Economie Rurale du Mali, Centre Régional de Recherche Agronomique de Sikasso, BP 16, Sikasso, Mali. \\ ${ }^{2}$ Institut Polytechnique Rural de Formation et de Recherche Appliquée, BP 06 Koulikoro, Katibougou, Mali. \\ ${ }^{3}$ Research Institute of Organic Agriculture, Department of Soil Sciences, Ackerstrasse 113, CH-5070 Frick, Switzerland.
}

How to cite this paper: Salif Doumbia, Sidiki Gabriel Dembele, Fagaye Sissoko, Odiaba Samake, Fernando Sousa, Cicek Harun, Noah Adamtey, Andreas Fliessbach. (2020) Alley Cropped Gliricidia sepium (Jacq.) Kunth ex. Walp. Enhance Soil Fertility and Yields of Cotton, Maize and Sorghum in Mali. International Journal of the Science of Food and Agriculture, 4(3), 301-313.

DOI: $10.26855 /$ ijfsa.2020.09.010

Received: July 21, 2020

Accepted: August 25, 2020

Published: September 3, 2020

*Corresponding author: Salif Doumbia, Institut d'Economie Rurale du Mali, Centre Régional de Recherche Agronomique de Sikasso, BP 16, Sikasso, Mali.

Email: doumbiasalif@gmail.com; salif.doumbia@ier.ml

\begin{abstract}
Mineral fertilizers are effective in boosting crop yields in most parts of the world. Under tropical conditions and especially in rain-fed arid ecosystems they are not effective, because the limitations of system productivity are stronger at the level of the climatic situation and soil quality. The positive effect of Gliricidia sepium (G. sepium) for: erosion control, shade, hydraulic lift, N-fixation, resource of fodder and soil input convinced the participating farmers to provide part of their land for this study. G. sepium was tested in association with cotton, maize and sorghum in order to develop best practices at two research stations and on fields of 30 farmers in the Sudanese and Sudano-Guinean zones of Mali. In addition to the introduction of G. sepium, the effects of organic and mineral fertilizers we tested at recommended and half rate. On-station experiments design was a split-plot with four replicates. The $\mathrm{pH}$, soil organic carbon and nitrogen in soil samples were analyzed from 0-20 cm depth taken in 2016 at the beginning of the experiment and in 2018. The average yields of cotton, maize and sorghum associated with $G$. sepium were $812,1,457$ and $1,377 \mathrm{~kg} \mathrm{ha}^{-1}$ respectively, whereas they were significantly lower without $G$. sepium reaching only $623,1,014$, and $807 \mathrm{~kg} \mathrm{ha}^{-1}$ respectively. In the third year after planting G. sepium, organic carbon contents and total soil nitrogen increased by $5 \%$ in soils between the alleys. Association of G. sepium with cotton, maize, and sorghum showed the improvement of crop yields and soil nitrogen content in addition to other advantages not considered for testing here. This finding may serve to improve small-scale farmer's livelihoods status through the improvement of soil fertility in Mali and the whole Sahel region.
\end{abstract}

\section{Keywords}

Gliricidia sepium, organic fertilizer, mineral fertilizer, cropping system, agroforestry

\section{Introduction}

The agricultural sector is the backbone of the economy of Sahelian ${ }^{1}$ countries. About $80 \%$ of the population in these countries lives in rural areas, and is depending on agriculture, fisheries and the exploitation of forest resources for their

${ }^{1}$ The Sahel stretches from Senegal on the Atlantic coast, through parts of Mauritania, Mali, Burkina Faso, Niger, Nigeria, Chad and Sudan to Eritrea on the Red Sea coast. 
livelihoods. Coupled effects of inappropriate agricultural practices and the negative effects of climate change are threatening the rural livelihoods in Sahel. Soils are degrading; and the size of available land for grazing is reducing, hence, the consequence of food insecurity and destabilized states and conflicts [1, 2, 3, 4]. In Mali, soil degradation affects up 22\% of arable land, which has become a major constraint of agricultural production [5]. Competition between field crops, livestock and humans for land, water, and biomass has been resulted into lower productive capacity and degraded land. According to this problem relates [6], among others, to the use of less productive or marginal lands, shorter fallow periods, overgrazing and overuse of vegetation cover, which lead to soil degradation (i.e., declined soil fertility and soil acidification).

In the recent decades, the increase in productivity in Mali has been achieved mainly through the expansion of cultivated land and soil mining by continuously removing soil nutrients without compensation. For instance, the area under maize increased from 59.247 ha in 2008 to 298.150 ha in 2017 [7]. Similarly, the area under cotton cultivation increased from 28.360 ha to 703.652 ha between 1960 and 2017 [8]. During this period, the Malian population increased fourfold, reaching around 19 Million people. Thus, the Malian Government faces the challenge of producing food to feed a constantly growing population while preserving the natural resources. Nutrient balances in cotton-based cropping systems in Mali are negative $[9,10,11]$ and macronutrient levels in soils are below the critical thresholds of $300 \mathrm{mg} \mathrm{N} \mathrm{g}^{-1}$ soil, 2.2 to $5.5 \mathrm{mgP} \mathrm{kg}^{-1}$ and 0.01 to 0.07 meqK $100 \mathrm{~g}^{-1}[12,13]$ indicating that $17 \%$ of soils in the cotton production zone have a $\mathrm{pH}$ below the threshold of 5.5. This soil acidification is directly responsible of the reduction of nutrients assimilation and consequently reducing crop growth and yields.

The organic and mineral amendments play an important role to improve soil quality and various soil properties particularly on leached tropical ferruginous soils $[14,15]$. Addition of organic amendments in these degraded soils has been shown to increase soil organic matter, $\mathrm{pH}$, water holding capacity and overall productivity [16]. Alternative biomass production methods using shrubs may alleviate some of the biomass shortage associated with crop-based agriculture and provide much-needed biomass for soil and livestock [17]. Local nutrient and organic matter source availability (i.e., shrub biomass) in Sahel is especially important considering limited availability, affordability and benefit of inorganic fertilizers.

Benefits of integrating shrubs/tress into Sahelian cropping systems are well-recognized but deep scientific understanding as well as large-scale uptake and implementation of such systems are rare $[18,16]$. Similarly, benefits of shrubs and trees providing ecosystems services (i.e., erosion control, biodiversity refuge, carbon sequestration, shading, food/fodder and medicine for animals and humans) and holding cultural significance for the population are widely recognized [19]. Studies demonstrated that Piliostigma reticulatum (DC.) Hochst., Guiera senegalensis J. F. Gmel. And Faidherbia albida (Del.) A. Chev. significantly promote crop growth, and improve soil quality [20, 21, 22, 23, 17] and reduce water stress $[24,25]$. Benefits from shrubs/tree are associated with the creation of "resource islands" triggering improved water and nutrient [24], microbial habitat, and soil physical properties [26, 27]. A recent study highlighted the hydraulic redistribution and bio irrigation ability of the Sahelian shrub Guiera senegalensis which closeness, increased nine-fold millet biomass production increased nine-fold [25].

Despite some evidences, a number of soil fertility management technologies are poorly adopted because of biophysical, economic or socio-cultural constraints [28]. It is imperative to introduce soil fertility management tools and technologies that are affordable to low-income producers and environmentally friendly. The participatory development of a technology with farmers, and their conviction of its positive impact on the household economy is crucial [29]. In this context, shrubs that can establish and grow fast, produce high amount of biomass, fix $\mathrm{N}_{2}$ and tolerate frequent coppicing are desired characteristics [30]. Furthermore, species that can be integrated into annual cropping systems with little or no risk for nutrient competition and shading with corps would be preferred over species that pose risk of nutrient competition and reduce photosynthetic activity [31,32]. Especially in cropping systems with high $\mathrm{N}$ demanding crops such as cotton and maize, easy availability and applicability of $\mathrm{N}$ rich shrub biomass is essential. Gliricidia sepium (Jacq.) Kunth ex. Walp. is one shrub species that can be integrated into maize and cotton based system, with negligible competition, an ability to withstand multiple times of coppicing provide high amount of $\mathrm{N}$ to the system [33] and increase the soil organic matter [32] which is particularly relevant for regions where availability and affordability of organic or inorganic soil amendments are limited.

The objective of this study was to develop, together with participating farmers, an agro-forestry technology based on G. sepium in the alley cropping system to improve soil fertility, crop productivity and establish food security in Sahel belt of Mali. The study hypothesis indicated that inclusion of G. Sepium into cotton based systems would significantly reduce the mineral fertilizer requirements, improve soil quality and water holding capacity and crop productivity. 


\section{Materials and Methods}

\subsection{The participatory process}

In 2016, the year before the initiation of field experiments, in the two selected study sites (ZoumanaDiassa in the Sikasso regions and Mafeya in the Koulikoro region), interdisciplinary research team contacted the farmers and together agreed on several approaches to improve soil fertility. Several techniques were discussed that might be useful to reduce the costs and inputs as well as to stabilize the yields by improving soil fertility. Participants agreed that agroforestry systems were the keyfor building (a) soil fertility because of numerous benefits it provided; fixing atmospheric nitrogen, providing shade, serving as a source of organic inputs and helping to stop erosion, (b) for food security by improving crop yield, reducing costs for fertilizers and serving as a fodder source for livestock during the dry season; and (c) for climate adaptation by protecting soil and building up soil organic matter. The disadvantages were discussed as well such as more manual labor during the management period of the alleys and a loss of land that is covered by the alleys. Since farmers were not using herbicides this was not a hindering factor to include more than one species in the field. At the end, 15 on-farm field trials and a replicated field experiment were established in each of the 2 regions.

\subsection{Sites}

The agroforestry systems with G. sepium alleys were tested in 2017 and 2018 at the research station of Institut Polytechnique Rural de Formation et de Recherche Appliquée (IPR/IFRA) in Katibougou, in the Koulikoro region and at the research station of Farako, Centre Regional de Recherche Agronomique (CRRA), Institutd' Economie Rurale (IER), in the Sikasso region (Table 1). The respective farmer groups were in the villages of Mafèya (Koulikoro) and ZoumanaDiassa (Sikasso). Around 30\% more rainfall has been received in Sikasso compared to Koulikoro region (Figure 1).

According to agro-ecological zones and crop rotation sequences, adapted varieties of sorghum, maize and cotton were used. In both stations and on farmers' fields, treatments included the woody G. sepium (Jacq.) Kunth ex. Walp. variety ILG50 (from ICRAF/Mali) intercropped with cotton (Gossypium hirsutum L., STAM59A) and maize (Zea mays L. hybrid Dembagnuma) in Sikasso and intercropped with sorghum (Sorghum bicolor L.) variety "CSM 63 E" and maize (Zea mays L. hybrid "brico”) at Koulikoro.

Table 1. Characteristics of the two study sites

\begin{tabular}{|c|c|c|}
\hline Characteristics & Katibougou & Farako \\
\hline Agro-ecological zones & Sudanian & Sudano-Guinean \\
\hline Administrative region & Koulikoro & Sikasso \\
\hline Location & $12^{\circ} 57^{\prime} \mathrm{S}, 7^{\circ} 36^{\prime} \mathrm{E}$ & 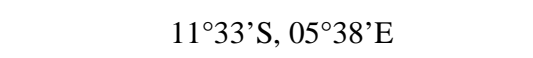 \\
\hline Annual average rainfall & $600-800 \mathrm{~mm}$ & $800-1,000 \mathrm{~mm}$ \\
\hline Soils [34] & Tropical ferruginous (Ultisols) & Tropical ferruginous (Alfisols) \\
\hline Average annual temperature & $21-26^{\circ} \mathrm{C}$ & $10-25^{\circ} \mathrm{C}$ \\
\hline Vegetation[35] & $\begin{array}{l}\text { Danielliaoliveri (Rolfe) Hutch. \& Dlz., } \\
\text { Vitellariaparadoxa Gaertn. f. } \\
\text { Terminalialaxiflora Engl. \& Diels } \\
\text { Detariummicrocarpum Guill. \& Perr., } \\
\text { Annonasenegalensis Pers. } \\
\text { Guierasenegalensis J. F. Gmel }\end{array}$ & $\begin{array}{l}\text { Guierasenegalensis } \\
\text { Parkiabiglobosa (Jacq.) Benth } \\
\text { Vitellariaparadoxa } \\
\text { Terminalialaxiflora } \\
\text { Annonasenegalensis } \\
\text { Faidherbiaalbida (Del.) A. Chev. } \\
\text { Danielliaoliveri } \\
\text { Detariummicrocarpum } \\
\text { Guierasenegalensis }\end{array}$ \\
\hline Climate aridity index & $0.25<$ IAC $<0.50$ & $0.25<$ IAC $<0.75$ \\
\hline Main crops & $\begin{array}{l}\text { Millet (Pennisetumamericanum L Leeke) } \\
\text { Sorghum (Sorghum bicolor L.) } \\
\text { Maize (Zea mays L.) }\end{array}$ & $\begin{array}{l}\text { Maize (Zea mays L.) } \\
\text { Millet (Pennisetumamericanum L Leeke) } \\
\text { Sorghum (Sorghum bicolor L.) } \\
\text { Cotton (Gossypiumhirsutum L) }\end{array}$ \\
\hline
\end{tabular}




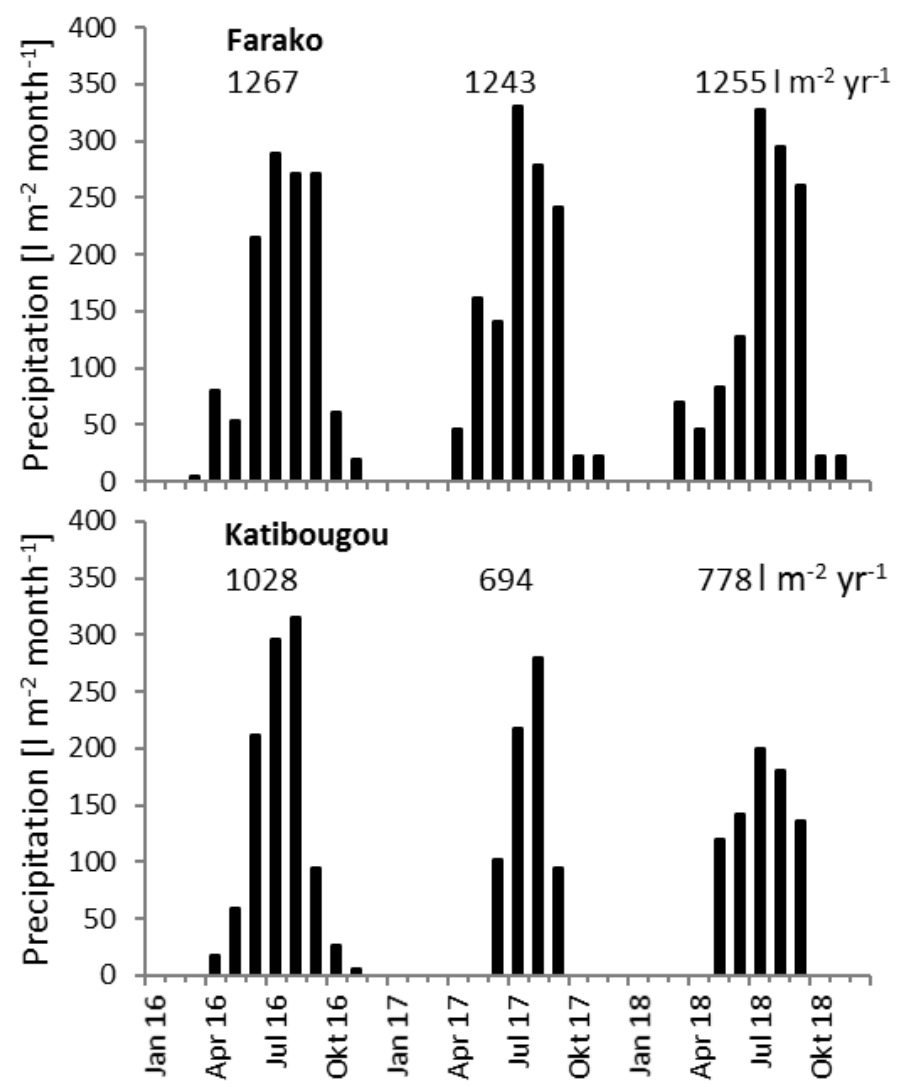

Figure 1. Rainfall in the years 2016 to 2018 in Farako and Katibougou.

\subsection{Soil characteristics in stations}

The results of the soil analyses at the onset of the two experiments showed that the soil at the field site in Farako in the Sikasso region was a sandy loamy while that of and the one at Katibougou was only loamy. The soils were slightly acidic with $\mathrm{pH}$ values of 5.4 and very low in soil organic matter, total soil nitrogen, $\mathrm{P}$, and $\mathrm{K}$ as examples of plant nutrients at both sites. This is a typical characteristic of soils in the region when they are used for crop production for a long time. Precipitation was relatively low in Katibougou compared to Farako. Especially in 2017 at Katibougou, the rainfall amount and distribution were not appropriate to give good growing conditions (Table 2).

Table 2. Physico-chemical characteristics of soil references in Sikasso and Koulikoro

\begin{tabular}{cccc}
\hline & Variables assessed & Farako & Katibougou \\
\hline & Clay [\%] & 15 & 14 \\
Physical properties (\%) & Silt [\%] & 8.3 & 38.8 \\
& Sand [\%] & 76.5 & 47 \\
& Max water holding capacity [\%] & 25.3 & 27. \\
& Textural class (WRB) & Sandy loam & 5.4 \\
Chemical characteristics & pH (KCl) & 5.4 & 4.5 \\
& Soil organic matter [\%] & 5.1 & 0.17 \\
$\mathrm{~N}$ [\%] & 0.11 & 0.03 \\
$\mathrm{P}(\mathrm{ppm})$ & 1.32 & 3.8 \\
& $\mathrm{~K}(\mathrm{ppm})$ & 4.17 & 7.54 \\
\hline
\end{tabular}




\subsection{Nutrient inputs}

Mineral fertilizer was applied according to the official recommendation to the particular crops (Table 3). Maize and sorghum were fertilized with a cereal complex fertilizer $15 \mathrm{~N}-15 \mathrm{P}-15 \mathrm{~K}$ at sowing time and urea 45 days after emergence. Cotton was fertilized with a cotton complex fertilizer 14N-10P-10K-7S-1B 15 days after sowing and urea 45 days after germination. The compost was prepared in a pit of $3 \times 3 \mathrm{~m}$ and $1 \mathrm{~m}$ depth, gradually filled withstraw, crop residues, household waste and animal waste. It was kept moist and was turned every 15 days at least 4 times. Compost was applied at 5 tha $^{-1}$ (full recommended rate) and $2.5 \mathrm{t} \mathrm{ha}^{-1}$ (half rate) every 2 years. Farmers were piling up the compost on the plots before spreading in May and June. Mineral fertilizer was applied according to the official recommendation to the crops in the following form: For maize and sorghum $100 \mathrm{~kg} \mathrm{ha}^{-1}$ of complex fertilizer (15P-15P-15K), 150 and 50 $\mathrm{kg} \mathrm{ha}^{-1}$ urea, respectively. For cotton, $200 \mathrm{~kg} \mathrm{ha}^{-1}$ cotton complex fertilizer (14N-22P-12K-7S-1B) and $50 \mathrm{~kg} \mathrm{ha}{ }^{-1} \mathrm{urea}$ $(46 \% \mathrm{~N})$ were applied on the field. The biomass of $\mathrm{G}$. sepium from pruning was collected and equally distributed to the respective plots with $G$. sepium alleys thereafter (Table 4).

Table 3. Nutrients as applied according to with mineral and organic fertilizer to the field plots fertilized at full-recommended rate

\begin{tabular}{|c|c|c|c|c|c|c|}
\hline & & $\mathrm{N}$ & $\mathrm{P}$ & K & $\mathrm{S}$ & B \\
\hline Crop & Fertilizer rate $\left(\mathrm{kg} \mathrm{ha}^{-1}\right)$ and type & & & $\mathrm{kg} \mathrm{ha}^{-1}$ & & \\
\hline \multirow[t]{3}{*}{ Maize } & 100 kg 15N-15P-15K & 15 & 15 & 15 & & \\
\hline & $150 \mathrm{~kg}$ urea $46 \mathrm{~N}$ & 69 & & & & \\
\hline & $5,000 \mathrm{~kg}$ compost & 49 & 9 & 64 & & \\
\hline \multirow[t]{3}{*}{ Cotton } & $200 \mathrm{~kg} 14 \mathrm{~N}-18 \mathrm{P}_{2} \mathrm{O}_{5}-18 \mathrm{~K}_{2} \mathrm{O}-6 \mathrm{~S}-1 \mathrm{~B}_{2} \mathrm{O}_{3}$ & 28 & 20 & 20 & 14 & 2 \\
\hline & 50 kg urea $46 \mathrm{~N}$ & 23 & & & & \\
\hline & $5,000 \mathrm{~kg}$ compost & 49 & 9 & 64 & & \\
\hline \multirow[t]{3}{*}{ Sorghum } & 100 kg 15N-15P-15K & 15 & 15 & 15 & & \\
\hline & $50 \mathrm{~kg}$ urea $46 \mathrm{~N}$ & 23 & & & & \\
\hline & $5,000 \mathrm{~kg}$ compost & 49 & 9 & 64 & & \\
\hline
\end{tabular}

Table 4. Biomass from pruning $G$. sepium and the related nutrient inputs based on the average nutrient content of $G$. sepium according to Kang (1984) $(4.21 \% \mathrm{~N}, 0.29 \% \mathrm{P}, 3.43 \% \mathrm{~K}$ and $1.40 \mathrm{Ca})$

\begin{tabular}{|c|c|c|c|c|c|c|}
\hline Site & Year & G. sepium (d.m.) & $\mathrm{N}$ & $\mathrm{P}$ & $\mathrm{K}$ & $\mathrm{Ca}$ \\
\hline & & \multicolumn{5}{|c|}{$\left[\mathrm{kg} \mathrm{ha}^{-1} \mathrm{yr}^{-1}\right]$} \\
\hline \multirow[t]{2}{*}{ Farako } & 2017 & 3,500 & 147.35 & 10.15 & 120.05 & 49.0 \\
\hline & 2018 & 3,600 & 151.56 & 10.44 & 123.48 & 50.4 \\
\hline \multirow[t]{2}{*}{ Katibougou } & 2017 & 1,400 & 58.94 & 4.06 & 48.02 & 19.6 \\
\hline & 2018 & 1,600 & 67.36 & 4.64 & 54.88 & 22.4 \\
\hline \multirow[t]{2}{*}{ ZoumanaDiassa } & 2017 & 2,800 & 117.88 & 8.12 & 96.04 & 39.2 \\
\hline & 2018 & 2,500 & 105.25 & 7.25 & 85.75 & 35.0 \\
\hline \multirow[t]{2}{*}{ Mafèya } & 2017 & 1,200 & 50.52 & 3.48 & 41.16 & 16.8 \\
\hline & 2018 & 1,400 & 58.94 & 4.06 & 48.02 & 19.6 \\
\hline
\end{tabular}

The experimental design was the split-plot with two cropping systems [with (+G) and without G. sepium (-G)] as main factor and five fertilizer treatments as secondary factor and replicated four times. The fertilizer treatments includeda control with no fertilizer (NF), two treatments with organic fertilizer at recommended rate (OF) and $50 \%$ reduced rate $(1 / 2 \mathrm{OF})$, and two treatments with mineral fertilizer at recommended rate $(\mathrm{MF})$ and $50 \%$ reduced rate $(1 / 2 \mathrm{MF})$. The two crops in the rotations maize-sorghum in Koulikoro and cotton-maize in Sikasso were grown each year on alternating subplots. Sorghum and maize have been sown at $0.80 \times 0.40 \mathrm{~m}$ spacing, cotton at $0.80 \times 0.30 \mathrm{~m}$ and $\mathrm{G}$. sepium at $4.80 \times 1 \mathrm{~m}$. The year before the experiment started a homogenous crop of cowpeas in Koulikoro and groundnut in Sikasso was cultivated.

G. sepium was planted during the cropping season in June 2016. In the following year, the well-established G. sepium 
plants were pruned to $0.5 \mathrm{~m}$ above ground level one to two weeks before the expected date of crop planting. All mulch from the individual plot was incorporated to the respective cropping area of each plot. Trees were pruned again when cotton, maize and sorghum reached a height of about $60 \mathrm{~cm}$ and mulch was applied between the crop rows. Trees were also prunedif they started to shade the crops and the shrub biomass was applied to soil as a mulch.

\subsection{Soil sampling and physico-chemical analysis}

Soil samples were taken after crop harvest as a composite sample of five soil cores taken with an auger from 0-20 cm depth. The samples were homogenized on a $2 \mathrm{~mm}$ sieve and air-dried at room temperature. All soil analyses were done at the soil laboratory of the Research Institute of Organic Agriculture (FiBL) in Switzerland. The methods were performed according to the reference methods of Swiss agricultural research stations [36]. The Maximum Water Holding Capacity (MWC) was determined after capillary water saturation and subsequent oversaturation of a soil sample. Soil $\mathrm{pH}$ was determined with an electrode in a soil water suspension (1:1). Total organic carbon (TOC) and total nitrogen (TN) content of the soil samples was determined using aVariomax CNS elemental analyser (Elementar GmbH, Hanau, Germany) baes on Dumas method [37]. Mineral Nitrogen (Nmin) was determined by spectroscopy on the Skalar Analyzer 1.

\subsection{Data analysis}

The yield and yield component and soil data obtained were statistically analyzed using Analysis of Variance. Performing with JMP Pro 14 and R 3.5.1 software. When the F values were significant, the comparison of the means between treatments was made with Tukey's HSD test.

\section{Results}

Maize and cotton were grown in the Sikasso region in both on-station and on-farm trials. In the Koulikoro region, maize and sorghum was cultivated. All crops were cultivated each year alternating among the two subplots. At the on-station trials, maize grain yield in 2017 was 43\% higher in Farako than in Katibougou and 100\% higher in 2018. From on farms, maize yield at Zoumana-Diassa in 2017 was 63\% higher, whilst it was 36\% lower in 2018 than in Mafèya.

\subsection{Maize and Sorghum in Koulikoro region}

On station trials, of $G$. sepium alleys had a clear positive effect with $48 \%$ higher yield at an average on crops and years (Table 5). In 2017, crops the yield increased with G. sepium up to $32 \%$ while it was, to $68 \%$ for the second year. Maize and sorghum yields were relatively poor with only compost or no fertilizer, but increased strongly with the use of commercial mineral fertilizer. It was only once that, crop yield with a given fertilizer was lower when grown with $G$. sepium compared to sole cropping.

Table 5. Sorghum and Maize grain yield at the on-station trial of IPR/IFRA in Katibougou in 2017 and 2018

\begin{tabular}{|c|c|c|c|c|c|c|c|c|c|}
\hline \multirow{2}{*}{\multicolumn{2}{|c|}{$\begin{array}{l}\text { Farming system and } \\
\text { Fertilizertreatments }\end{array}$}} & \multicolumn{4}{|c|}{ Maizegrainyield $\left[\mathrm{kg} \mathrm{ha}^{-1}\right]$} & \multicolumn{4}{|c|}{ Sorghum grainyield $\left[\mathrm{kg} \mathrm{ha}^{-1}\right]$} \\
\hline & & \multicolumn{2}{|c|}{2017} & \multicolumn{2}{|c|}{2018} & \multicolumn{2}{|c|}{2017} & \multicolumn{2}{|c|}{2018} \\
\hline +G. sepium & MF & 1,932 & $\mathrm{a}$ & 1,385 & $\mathrm{ab}$ & 1,448 & $\mathrm{a}$ & 2,674 & a \\
\hline +G. sepium & $1 / 2 \mathrm{MF}$ & 1,271 & abc & 1,439 & $\mathrm{a}$ & 1,125 & $\mathrm{ab}$ & 2,154 & $a b$ \\
\hline +G. sepium & $\mathrm{OF}$ & 761 & $\mathrm{~cd}$ & 1,065 & bc & 1,188 & $\mathrm{ab}$ & 1,356 & bcd \\
\hline +G. sepium & $1 / 2 \mathrm{OF}$ & 401 & $\mathrm{~d}$ & 1,200 & abc & 698 & bc & 1,381 & bcd \\
\hline +G. sepium & NF & 360 & d & 975 & $\mathrm{~cd}$ & 771 & bc & 975 & cde \\
\hline -G. sepium & MF & 1,500 & $\mathrm{ab}$ & 860 & cde & 1,057 & abc & 1,903 & $\mathrm{abc}$ \\
\hline -G. sepium & $1 / 2 \mathrm{MF}$ & 1,193 & bc & 972 & $\mathrm{~cd}$ & 776 & bc & 1,621 & abc \\
\hline -G. sepium & $\mathrm{OF}$ & 328 & d & 556 & e & 839 & bc & 291 & de \\
\hline -G. sepium & $1 / 2 \mathrm{OF}$ & 448 & d & 570 & e & 667 & bc & 221 & de \\
\hline -G. sepium & $\mathrm{NF}$ & 219 & $\mathrm{~d}$ & 650 & de & 542 & C & 157 & e \\
\hline \multicolumn{10}{|l|}{ ANOVA } \\
\hline \multicolumn{10}{|l|}{ Effects } \\
\hline G. sepium & & $128 \%$ & & $168 \% *$ & & $135 \% *$ & & $204 \% *$ & \\
\hline Fertilizer & & $*$ & & & & & & * & \\
\hline
\end{tabular}

The on-farm trials at Mafèya showed a tendency towards higher yield with G. sepium (Table 6). The full rate of mineral fertilizer always produced the highest yield. In 2018, crop yields were much higher than that of 2017 even at low 
fertilizer rate. This could be due to growing conditions probably been much better in general. The organic fertilizer amendment only caught up with the other treatments in 2018 in the maize crop, where all treatments seemed to give good yields because of sufficient rain. Compared to the on-farm trials, the yields of on stations trials in 2017 did not differ much for both crops. But in 2018, the yields of sorghum and maize were respectively 139 and $79 \%$ higher on farm than on station in the Koulikoro region.

Table 6. Sorghum and Maize grain yield at the on-farm trials of Mafèya, Koulikoro region in 2017 and 2018

\begin{tabular}{|c|c|c|c|c|c|c|c|c|}
\hline \multirow{2}{*}{ Farming system } & \multicolumn{4}{|c|}{ Sorghum } & \multicolumn{4}{|c|}{ Maize } \\
\hline & \multicolumn{2}{|c|}{2017} & \multicolumn{2}{|c|}{2018} & \multicolumn{2}{|c|}{2017} & \multicolumn{2}{|c|}{2018} \\
\hline $\mathrm{MF}+$ G. sepium mulch & 1,096 & a & 3,486 & $\mathrm{a}$ & 1,431 & $\mathrm{a}$ & 3,978 & $\mathrm{a}$ \\
\hline MF & 961 & $\mathrm{ab}$ & 2,610 & $a b$ & 997 & $\mathrm{ab}$ & 2,925 & a \\
\hline $1 / 2 \mathrm{MF}+$ G. sepium mulch & 734 & $\mathrm{~b}$ & 1,880 & $\mathrm{~b}$ & 823 & $\mathrm{~b}$ & 2,203 & a \\
\hline $1 / 2 \mathrm{MF}+\mathrm{OF}$ & 808 & $\mathrm{ab}$ & 1,252 & $\mathrm{~b}$ & 1,141 & $a b$ & 2,936 & a \\
\hline
\end{tabular}

$\mathrm{n}=14$; different letters behind means indicate significant difference in the Tukey HSD test at $p=0.05$.

\subsection{Maize and Cotton in the Sikasso region}

The cotton seed-fiber yield was 30-33\% higher with G. sepium amendment in both years at Farakoon station trial (Table 7). While cotton yields in the on-station trial were not significantly influenced by the mineral fertilizer rates in 2017, they were markedly higher with mineral fertilization in 2018 compared to all other fertilizer treatments. There was no interaction effect of $G$. sepium application with fertilization on crop yields. The maize crop at Farako yielded $19 \%$ more grains with G. sepium in 2017, but $62 \%$ in the second year. The mineral fertilizer at recommended rate produced the highest maize yield in both years, but the yield in 2018 was exceptionally high. With 3.8 tons per hectare, it was almost 90\% higher in 2017. At half rate, the yield decreased by 15\% in 2017 and 31\% in 2018 with organic fertilizer. Yield was 60\%-70\% lower compared to the system with mineral fertilizer at recommended rate.

Table 7. Maize grain yield and cotton seed-fibre yield at the on-station trial of IER/CRRA in Farako, Sikasso region in 2017 and 2018

\begin{tabular}{|c|c|c|c|c|c|c|c|c|c|}
\hline \multirow{2}{*}{\multicolumn{2}{|c|}{$\begin{array}{l}\text { Farming system and } \\
\text { Fertilizer treatments }\end{array}$}} & \multicolumn{4}{|c|}{ Cotton seed-fiber yield $\left[\mathrm{kg} \mathrm{ha}^{-1}\right]$} & \multicolumn{4}{|c|}{ Maize grain yield [ $\left.\mathrm{kg} \mathrm{ha}^{-1}\right]$} \\
\hline & & \multicolumn{2}{|l|}{2017} & \multicolumn{2}{|c|}{2018} & \multicolumn{2}{|c|}{2017} & \multicolumn{2}{|c|}{2018} \\
\hline +G. sepium & MF & 1,055 & a & 1,313 & $\mathrm{a}$ & 1,783 & abc & 4,552 & $\mathrm{a}$ \\
\hline +G. sepium & $1 / 2 \mathrm{MF}$ & 772 & a & 959 & b & 2,018 & $a b$ & 3,071 & $\mathrm{~b}$ \\
\hline +G. sepium & OF & 717 & $\mathrm{a}$ & 900 & bc & 1,022 & bcd & 1,402 & $\mathrm{~cd}$ \\
\hline +G. sepium & $1 / 2 \mathrm{OF}$ & 530 & $\mathrm{a}$ & 721 & bcd & 848 & bcd & 1,366 & $\mathrm{~cd}$ \\
\hline +G. sepium & NF & 531 & $\mathrm{a}$ & 625 & de & 858 & bcd & 1,433 & $\mathrm{~cd}$ \\
\hline -G. sepium & MF & 719 & a & 871 & bcd & 2,250 & a & 2,992 & $\mathrm{~b}$ \\
\hline -G. sepium & $1 / 2 \mathrm{MF}$ & 541 & $\mathrm{a}$ & 792 & bcd & 1,406 & abcd & 2,103 & bc \\
\hline -G. sepium & OF & 543 & a & 675 & cde & 561 & d & 866 & $\mathrm{~cd}$ \\
\hline -G. sepium & $1 / 2 \mathrm{OF}$ & 586 & $\mathrm{a}$ & 621 & de & 846 & $\mathrm{~cd}$ & 1,078 & $\mathrm{~cd}$ \\
\hline -G. sepium & NF & 455 & $\mathrm{a}$ & 425 & e & 443 & d & 434 & $\mathrm{~d}$ \\
\hline \multicolumn{10}{|l|}{ ANOVA } \\
\hline \multicolumn{10}{|l|}{ Effects } \\
\hline G. sepium & & $127 \%$ & & $134 \%$ & & $119 \%$ & & $158 \% *$ & \\
\hline Fertilizer & & $*$ & & * & & $*$ & & * & \\
\hline
\end{tabular}

$\mathrm{n}=4$; different letters behind means and asterisks * indicate significant difference in the Tukey HSD test or ANOVA effects at $p=0.05$. 
At the on-farm trials in Zoumana Diassa, the amendment with G. sepium biomass showed a trend towards higher cotton and maize yield at recommended mineral fertilizer rate (Table 8). The compost amendment together with half rate of mineral fertilizer, however, was only effective in one out of four crop years. On-farm yields in 2017 were about $50 \%$ higher than that of on station. In 2018, there was not much difference between on farm and on station trials' results.

Table 8. Maize grain yield and cotton seed-fiber yield at the on-farm trials in Zoumana-Diassa, Sikasso region in 2017 and 2018

\begin{tabular}{|c|c|c|c|c|c|c|c|c|}
\hline \multirow[t]{2}{*}{ Treatment } & \multicolumn{4}{|c|}{ Maize } & \multicolumn{4}{|c|}{ Cotton } \\
\hline & \multicolumn{2}{|c|}{2017} & \multicolumn{2}{|c|}{2018} & \multicolumn{2}{|c|}{2017} & \multicolumn{2}{|c|}{2018} \\
\hline $\mathrm{MF}+G$. sepium mulch & 1,945 & a & 2,213 & $\mathrm{a}$ & 903 & $\mathrm{a}$ & 728 & $\mathrm{a}$ \\
\hline MF & 1,436 & a & 1,959 & $\mathrm{a}$ & 1,020 & $\mathrm{a}$ & 646 & $\mathrm{a}$ \\
\hline $1 / 2 \mathrm{MF}+$ G.sepium mulch & 1,869 & $\mathrm{a}$ & 1,924 & $\mathrm{a}$ & 767 & $\mathrm{a}$ & 696 & $\mathrm{a}$ \\
\hline $1 / 2 \mathrm{MF}+\mathrm{OF}$ & 1,918 & $\mathrm{a}$ & 1,631 & $\mathrm{a}$ & 793 & $\mathrm{a}$ & 472 & a \\
\hline
\end{tabular}

$\mathrm{n}=15$; different letters behind means indicate significant difference in the Tukey HSD test at $p=0.05$.

\subsection{Effect of $G$. sepium mulch applications on soil quality in 2018 after two cropping seasons}

The pH of the Farako site was slightly lower than the one from Katibougou. The effect of G. sepium application appeared to increase the $\mathrm{pH}$ value (Table 9), while there was no effect of the fertilizer types and quantities on $\mathrm{pH}$.

Table 9. Effects of the cropping system on soil pH (water) Sikasso and Koulikoro

\begin{tabular}{|c|c|c|c|c|c|}
\hline \multirow{2}{*}{\multicolumn{2}{|c|}{$\begin{array}{l}\text { Farming system and } \\
\text { fertilizer treatments }\end{array}$}} & \multirow{3}{*}{$\begin{array}{c}\begin{array}{c}\text { Farako } \\
\mathrm{pH}(\mathrm{H} 2 \mathrm{O})\end{array} \\
6.4\end{array}$} & \multirow{3}{*}{$\begin{array}{l}\text { SD } \\
0.4\end{array}$} & \multirow{3}{*}{$\begin{array}{c}\text { Katibougou } \\
\mathrm{pH}(\mathrm{H} 2 \mathrm{O}) \\
6.701\end{array}$} & \multirow{3}{*}{$\frac{\mathrm{SD}}{0.399}$} \\
\hline & & & & & \\
\hline$+G$. sepium & MF & & & & \\
\hline$+G$. sepium & $1 / 2 \mathrm{MF}$ & 6.5 & 0.4 & 6.699 & 0.347 \\
\hline+ G. sepium & $\mathrm{OF}$ & 6.6 & 0.4 & 6.763 & 0.330 \\
\hline+ G. sepium & $1 / 2 \mathrm{OF}$ & 6.4 & 0.4 & 6.585 & 0.435 \\
\hline+ G. sepium & $\mathrm{NF}$ & 6.5 & 0.4 & 6.670 & 0.334 \\
\hline -G. sepium & MF & 6.0 & 0.6 & 6.180 & 0.593 \\
\hline -G. sepium & $1 / 2 \mathrm{MF}$ & 6.0 & 0.6 & 6.181 & 0.541 \\
\hline -G. sepium & $\mathrm{OF}$ & 6.2 & 0.5 & 6.420 & 0.411 \\
\hline -G. sepium & $1 / 2 \mathrm{OF}$ & 6.1 & 0.7 & 6.351 & 0.503 \\
\hline -G. sepium & NF & 6.1 & 0.6 & 6.434 & 0.394 \\
\hline \multicolumn{6}{|l|}{ ANOVA } \\
\hline \multirow[t]{2}{*}{ Sites } & Farako & 6.3 & $\mathrm{~b}$ & & \\
\hline & Katibougou & 6.5 & $\mathrm{a}$ & & \\
\hline \multirow[t]{2}{*}{ Farming system } & $+G$. sepium & 6.6 & $\mathrm{a}$ & & \\
\hline & -G. sepium & 6.2 & $\mathrm{~b}$ & & \\
\hline \multirow[t]{3}{*}{ Factor effects } & Site & 0.0031 & & & \\
\hline & Farming system & $<.0001$ & & & \\
\hline & Fertilization & 0.5529 & & & \\
\hline
\end{tabular}

$\mathrm{n}=40$.

At both sites, the soil organic carbon (Corg) and total nitrogen contents were below 1\% (Table 10). In 2018, Corgat Farako with sandy soil texture averaged at $2.1 \mathrm{mg} \mathrm{kg}^{-1}$ and $3.7 \mathrm{mg} \mathrm{kg}^{-1}$ at Katibougou with $80 \%$ higher than Corg fromFarako, with its very sandy soils. Total nitrogen contents were 0.2 and $0.3 \mathrm{mg} \mathrm{kg}^{-1}$ at Farako and Katibougou, respectively; C-to-N ratios therefore were slightly higher in Katibougou (12.1) than in Farako (10.3). 
In the third year after planting G. sepium and two cropping seasons, organic carbon and total soil nitrogen was 5-6\% higher in plots with G. sepium compared to those without (Table 10). The effect of the mineral and organic fertilizers was relatively small and not significant. Comparing each fertilizer amendment with and without $G$. sepium, only the half rate organic fertilizer and the unfertilized control at Katibougou showed lower Corg and TN values with G. sepium compared to sole cropping. All others showed an increase in this important soil quality indicator.

Table 10. Effects of cropping systems and fertilizer application on soil organic carbon and total nitrogen in the on-station trials at Farako and Katibougou in 2018

\begin{tabular}{|c|c|c|c|c|c|c|c|c|c|}
\hline \multirow{2}{*}{\multicolumn{2}{|c|}{$\begin{array}{l}\text { Farming system and } \\
\text { fertilizer treatments }\end{array}$}} & \multicolumn{2}{|l|}{ Farako } & \multicolumn{2}{|c|}{ Katibougou } & \multicolumn{2}{|c|}{ Farako } & \multicolumn{2}{|c|}{ Katibougou } \\
\hline & & \multirow{2}{*}{$\frac{\text { Corg }\left[\mathrm{mg} \mathrm{kg}^{-1}\right]}{2.23}$} & \multirow{2}{*}{$\frac{\mathrm{SD}}{0.37}$} & \multirow{2}{*}{$\frac{\text { Corg [mg kg-1 }]}{4.07}$} & \multirow{2}{*}{$\frac{\mathrm{SD}}{0.51}$} & \multirow{2}{*}{$\frac{\mathrm{Nt}\left[\mathrm{mg} \mathrm{kg}^{-1}\right]}{0.215}$} & \multirow{2}{*}{$\frac{\mathrm{SD}}{0.031}$} & \multirow{2}{*}{$\frac{\mathrm{Nt}\left[\mathrm{mg} \mathrm{kg}^{-1}\right]}{0.349}$} & \multirow{2}{*}{$\frac{\mathrm{SD}}{0.038}$} \\
\hline +G. sepium & MF & & & & & & & & \\
\hline +G. sepium & $1 / 2 \mathrm{MF}$ & 2.13 & 0.21 & 3.90 & 0.74 & 0.204 & 0.031 & 0.320 & 0.055 \\
\hline +G. sepium & $\mathrm{OF}$ & 2.09 & 0.24 & 3.66 & 0.47 & 0.206 & 0.028 & 0.301 & 0.041 \\
\hline +G. sepium & $1 / 2 \mathrm{OF}$ & 2.16 & 0.38 & 3.46 & 0.78 & 0.213 & 0.037 & 0.291 & 0.062 \\
\hline +G. sepium & NF & 2.14 & 0.28 & 3.47 & 0.46 & 0.204 & 0.029 & 0.284 & 0.03 \\
\hline -G. sepium & MF & 1.95 & 0.41 & 3.57 & 0.66 & 0.186 & 0.031 & 0.286 & 0.04 \\
\hline -G. sepium & $1 / 2 \mathrm{MF}$ & 1.84 & 0.29 & 3.62 & 0.46 & 0.188 & 0.028 & 0.315 & 0.033 \\
\hline -G. sepium & $\mathrm{OF}$ & 2.06 & 0.32 & 3.36 & 0.42 & 0.203 & 0.03 & 0.279 & 0.031 \\
\hline -G. sepium & $1 / 2 \mathrm{OF}$ & 2.01 & 0.29 & 3.70 & 0.38 & 0.198 & 0.029 & 0.296 & 0.034 \\
\hline -G. sepium & NF & 1.94 & 0.25 & 3.74 & 0.64 & 0.188 & 0.023 & 0.305 & 0.039 \\
\hline \multicolumn{10}{|l|}{ ANOVA results } \\
\hline \multirow[t]{2}{*}{ Sites } & Farako & & & 2.05 & $\mathrm{~b}$ & & & 0.200 & $\mathrm{~b}$ \\
\hline & \multicolumn{2}{|c|}{ Katibougou } & & 3.65 & $\mathrm{a}$ & & & 0.303 & a \\
\hline \multirow[t]{2}{*}{ Farming system } & \multicolumn{2}{|c|}{ +G. sepium } & & 2.93 & $\mathrm{a}$ & & & 0.259 & a \\
\hline & \multicolumn{2}{|c|}{-G. sepium } & & 2.78 & $\mathrm{~b}$ & & & 0.244 & $\mathrm{~b}$ \\
\hline \multirow[t]{3}{*}{ Factor effects } & \multicolumn{2}{|l|}{ Site } & & \multicolumn{2}{|l|}{$<.0001$} & & \multicolumn{3}{|c|}{$<.0001$} \\
\hline & \multicolumn{2}{|c|}{ Farming system } & & \multicolumn{2}{|l|}{0.0183} & & \multicolumn{3}{|c|}{0.0049} \\
\hline & \multicolumn{2}{|c|}{ Fertilization } & & \multicolumn{2}{|l|}{0.5075} & & \multicolumn{3}{|c|}{0.3253} \\
\hline
\end{tabular}

\section{Discussion}

\subsection{Production of $G$. sepium biomass}

The on-station average annual biomass production (dry matter) of $G$. sepium were 3.5 tha $^{-1}$ at Farako in the Sudano-Guinean zone and 1.5 tha $^{-1}$ at IPR/IFRA of Katibougou in the Sudanese zone. The biomass from pruning on farms trials averaged at $2.6 \mathrm{t}^{-\mathrm{ha}^{-1}}$ in Zoumana Diassa and $1.3 \mathrm{t}^{\mathrm{h}} \mathrm{ha}^{-1}$ at Mafèya. These figures were within the reported range of 3.5 to 3.6 t. ha $^{-1}$ for Farako and below for Katibougou [38, 39]. Assuming around $4 \% \mathrm{~N}$ biomass content and no inorganic N input, in order to meet the maize and cotton N requirements, G. Sepium, needs to produce at least $4 \mathrm{t}^{\mathrm{n}} \mathrm{ha}^{-1}$ of dry matter. In the current study, the maximum amount was 3.5 t. ha ${ }^{-1}$ at Farako. Lower biomass production of $G$. Sepium under drier conditions was also reported by [40]. It appears that the $1.5 \mathrm{t} \mathrm{ha}^{-1}$ biomass production in drier site of Katibougou is not sufficient to meet crop $\mathrm{N}$ demand and needs to be amended with inorganic fertilizers for optimum crop production.

\subsection{Physical and chemical properties of soils}

Alley cropping systems with $G$. sepium and its coppiced biomass as a mulch can help maintaining and improving the physical and chemical characteristics of soils [41, 42, 43, 44, 45, 46, and 47]. Considering the great advantages of alley cropping systems in arid ecosystem agriculture, poor adoption and development of this farming system warrant further investigation [48, 49, and 50]. Only with respect to crop yield and soil quality measured as $\mathrm{pH}$, organic carbon and organic nitrogen, the effects of alley cropping system with G. sepium were already significant after three years in our 
study.

In view of the poor soils at the study sites, the increasing organic carbon content was a valuable improvement in soil quality. Not only that it helps to sequester $\mathrm{CO}_{2}$ in soils, it may enhance soil structure, water retention capacity, porosity and soil fertility [51, 52, 53, 54, 55, 56, 57, and 58]. In arid ecosystems, the role and benefits of soil organic matter are particularly related to the physical, biological and chemical properties of soils [59, 52, and 60]. Our results also support the notion that an improvement of soil quality as well as other conditions for crop growth render soils and the farming system responsive to fertilizers, one of the goals of integrated soil fertility management (ISFM)[61, 62, 63].

Total nitrogen levels increased concomitant with the increasing organic matter content and showed advantages for the systems with $G$. sepium. Its mulch has a low $\mathrm{C} / \mathrm{N}$ ratio $(<12)$, which is easily decomposable $[64,65]$ and serves as an easily available plant nutrient providing organic matter that may enter the soil organic carbon pool [66]. Our results support the enhanced effectiveness of fertilizer use, when a permanent crop such as G. sepium protects the field. The work of [67] showed that nitrogen mineralization in sandy soils was strongly stimulated by root biomass when the plant's $\mathrm{N}$ requirements are higher than the amount available in the soil (otherwise the plant directs the internal nitrogen cycle towards reorganization).

\subsection{Yield of cotton, maize and sorghum grain}

The introduction of $G$. sepium improved yields of cotton, maize and sorghum, endorsing the attempts to promote agroforestry and alley cropping systems in West Africa. G. sepium affects the quantity and quality of chemical, biological and physical components of the soil, which in turn improve yields. The results of alley cropping trials at research stations in Mali confirm the potential of G. sepium to improve soil fertility and yields of associated crops [68, 43].

Maize yield was improved by $19 \%$ in 2017 and 56\% in 2018 compared to the control without G. sepium at Farako. At Katibougou, an improvement of 28\% in 2017 and 61\% in 2018 was observed compared to the control without G. sepium. Sorghum grain yield was improved by 35\% in 2017 and 34\% in 2018 compared to the control without G. sepium. These results confirmed those obtained in Senegal by [44] who has shown that the use of G. sepium mulch as a green manure increased maize biomass and grain yields by $25 \%$ and $9 \%$ respectively compared to the control without $G$. sepium mulch. According to the same source when the biomass used comes from G. sepium plants inoculated with strains of Rhizobium and mycorrhizal fungi in combination, the grain yield of maize increased by $130 \%$ compared to the control.

The results of the alley cropping trials with G. sepium confirm the potential for improving maize and sorghum yields. Giller et al. [69] reported on possible nitrogen-fixing rates of G. sepium from 170-204 $\mathrm{kg} \mathrm{N} \mathrm{ha}^{-1}$, which is an enormous capital these intercropped shrubs are providing. At the two stations (Katibougou and Farako) and in rural areas, maize yields varied between 1,134 and 4,500 $\mathrm{kg} \mathrm{ha}^{-1}$. These results are closed to those obtained in southern Africa where the use of G. sepium litter maintained maize yields between 1,800 and 3,000 kg. ha ${ }^{-1}[70]$. These authors reported that yield is often dependent on biomass quality. The low water holding capacity (Table 2) makes the production systems depending on a constant rainfall at both sites.

\section{Conclusion}

At the end of this work, it appears that G. sepium used as a green manure or in combination with mineral fertilizers and compost over three growing seasons significantly improved the soil $\mathrm{pH}$, organic carbon total nitrogen. Yields of cotton, sorghum and maize crops were much higher, sometimes doubling through the association with G. sepium. The participating farmers appreciated the G. sepium alley cropping system because of the higher yields and the easiest practice of the technology. Therefore, it can be concluded that alley cropping with G. sepium is a technology that has a high potential for scaling up to the farmers of the Sudanian and Sudano-Guinean zones of Mali, who already expressed their interest at farmer field days and developed tree nurseries to spread this technique.

Despite the interesting results obtained, farmers are also expressing their doubts, because the recommended species for the alley cropping system are not providing edible (by)-products, which seem to discourage farmers to adopt the technology. They also see limitations in the lack of work force at peak times when the periodic maintenance of the shrub alleys should take place and in the need for protecting young plants that are not yet fully established from browsing animals.

\section{Acknowledgements}

This study is part of the project "Farmer driven organic resource management to build soil fertility (ORM4Soil; Grant No. 400540-152224)", which is funded in the frame of the Swiss Programme for Research on Global Issues for Development (r4d programme), launched by the Swiss Agency for Development and Cooperation (SDC) and the Swiss National Science Foundation (SNSF). The authors are grateful to the funding organizations, the thoughtful guidance by the project officers and the critical advice by the scientific committee. The skilled technical assistance of Anton Kuhn and Adolphe Munyangabe in the FiBL laboratories is gratefully acknowledged. The authors are grateful to the participating farmers and the numerous helpers in the field. 


\section{References}

[1] Breman. H., de Ridder, N. (1991). Manuel sur les pâturages des pays sahéliens. KARTHALA Editions, Wageningen.

[2] Bationo, A., Lompo, F., Koala, S. (1998). Research on nutrient flows and balances in west Africa: state-of-the-art. Int. J. Agric. Ecosys. Environ, 71: 19-35.

[3] Comité Permanent Inter-États de Lutte Contre la Sécheresse dans le Sahel (CILSS). (2002). Réglementation commune aux états membres du CILSS sur l’homologation des pesticides, Ouagadougou, Burkina Faso.

[4] Konaté F. (2008). Démographie - Environnement Croissance démographique et systèmes de production au plateau dogon au Mali(éd.). Tome, P.U.O., Cahiers du CERLESHS: Ouagadougou.

[5] FAO., FIDA., PAM. (2015). L’Etat de l'insecurité alimentaire dans le monde. Objectifs internationaux 2015 de réduction de la faim: des progrès inégaux (éd.). FAO, Rome.

[6] Jones, A., Breuning-Madsen H., Brossard, M., Dampha, A., Deckers, J., Dewitte, O., Gallali, T., Hallett, S., Jones, R., Kilasara, M., Le Roux, P., Micheli, E., Montanarella, L., Spaargaren, O., Thombiano, L., Van Ranst, E., Yemefack, M., Zougmoré, R. (2013). Soil atlas of Africa (éd.). Union Européenne, Luxembourg.

[7] Direction Nationale de l’Agriculture (DNA). (2017). Rapport annuel 2017. In: l’Agriculture, M.d., Ministère de l’Agriculture, Bamako, Mali.

[8] Compagnie Malienne de Développement des Textiles (CMDT) (2018). Annuaire statistique 2016/2017. Résultats de l'enquête agricole permanente. In: (DPCG), D.d.l.p.d.c.g, CMDT, Bamako.

[9] Van der Pol, F., Traore, B. (1993). Soil nutrient depletion by agricultural production in Southern Mali. Fertilizer Research, 36: 79-90.

[10] Kanté, S. (2001). Gestion de la fertilité des sols par classe d'exploitation au Mali-Sud. Ph.D. Dissertation, Wageningen University, Wageningen.

[11] Sissoko, F., Rapidel, B., Gaborel, C., Renou, A., Aya, O. (2005). Identification des déficiences minérales sur cotonnier au Mali à partir des symptômes visuels.

[12] Dembele, D., Traore, K., Quansah, C., Osei Jnr, E. M., Bocar, D. S. B. A., Ballo, M. (2016). Optimizing Soil Fertility Management Decision in Mali by Remote Sensing and GIS. Int. J. of Agricultural Research, 3(4): 022-034.

[13] Sissoko, F., Coulibaly, D., Cissé, O., Dugué, P. (2015). Évaluation de l'arrière effet de la culture du coton sur la production céréalière en zone cotonnière du Mali. In: Fok, M.N.O.K.S. (éd.), Conference of African Research on Agriculture, Food and Nutrition, Yamoussoukro.

[14] Pieri, C. (1985). Bilans mineraux des systèmes de cultures pluviales en zones arides et semi-arides. Int. J. L'agronomie tropicale, 40: 1-20.

[15] FAO. (2004). Utilisation des phosphates naturels pour une agriculture durable. Rome, Italy.

[16] Bayala, J., Sanou, J., Teklehaimanot, Z., Kalinganine, A., Ouédraogo, S. J. (2014). Parklands for buffering climate risk and sustaining agricultural production in the Sahel of West Africa. Int. J. Elsevier, 6: 28-34.

[17] Dossa, E. L., Diedhiou, I., Khouma, M., Sene, M., Badiane, A. N., Samba, N., Samba, A., Assigbetse, K. B., Sall, S., Lufafa, A. (2013). Crop productivity and nutrient dynamics in a shrub-based farming system of the Sahel. Int. J. Agron, 105(4): 1237-1246.

[18] Lahmar, R., Bationo, B. A., Dan Lamso, N., Guéro, Y., Tittonell, P. (2012). Tailoring conservation agriculture technologies to West Africa semi-arid zones: Building on traditional local practices for soil restoration. Int. J. Field Crops Res, 132: 158-167.

[19] Bado, B. V., Savadogo, P., Manzo, M. L. S. (2016). Restoration of Degraded Lands in West Africa Sahel: Review of experiences in Burkina Faso and Niger. Technical Report, ICRISAT.

[20] Roupsard, O., Ferhi, A., Granier, A., Pallo, F., Depommier, D., Mallet, B., Joly, H. I., Dreyer, E. (1999). Reverse phenology and dry-season water uptake by Faidherbia albida (Del.) A. Chev. in an agroforestry parkland of Sudanese west Africa. Int. J. Functional Ecology, 13: 460-472.

[21] Lufafa, A., Diédhiou, I., Samba, S. A. N., Séné, M., Khouma, M., Kizito, F., Dick, R. P., Dossa, E., Noller, J. S. (2008). Carbon stocks and patterns in native shrub communities of Senegal's Peanut Basin. Int. J. Geoderma, 146: 75-82.

[22] Dossa, E., Khouma, M., Diedhiou, I., Sene, M., Kizito, F., Badiane, A., Samba, S., Dick, R. (2009). Carbon, nitrogen and phosphorus mineralization potential of semiarid Sahelian soils amended with native shrub residues. Int. J. Geoderma, 148: 251-260.

[23] Dossa, E., Diedhiou, I., Khouma, M., Sene, M., Lufafa, A., Kizito, F., Samba, S., Badiane, A., Diedhiou, S., Dick, R. (2012). Crop productivity and nutrient dynamics in a shrub (Guierasenegalensis)-based farming system of the Sahel. Int. J. Agron, 04(5): 1255-1264.

[24] Kizito, F., Dragila, M., Senè, M., Brooks, J., Meinzer, F., Diedhiou, I., Diouf, M., Lufafa, A., Dick, R., Selker, J. (2012). Hydraulic redistribution by two semi-arid shrub species: Implications for Sahelian agro-ecosystems. Int. J. Arid Environ, 83: 69-77. 
[25] Bogie, N. A., Bayala, R., Diedhiou, I., Conklin, M. H., Fogel, M. L., Dick, R. P. and Ghezzehei, T. A. (2018). Hydraulic Redistribution by Native Sahelian Shrubs: Bioirrigation to Resist In-Season Drought. Front. Environ. Sci, 6: 98.

[26] Diedhiou, S., Dossa, E., Badiane, A., Diedhiou, I., Sene, M., Dick, R. (2009). Decomposition and spatial microbial heterogeneity associated with native shrubs in soils of agroecosystems in semi-arid Senegal. Int J. Pedobiologia, 52: 273-286.

[27] Hernandez, R. R., Debenport, S. J., Leewis, M.-C. C., Ndoye, F., Soumare, A., Thuita, M., Gueye, M., Miambi, E., Chapuis-Lardy, L., Diedhiou, I. (2015). The native shrub, Piliostigma reticulatum, as an ecological "resource island" for mango trees in the Sahel. Int. J. Agric. Ecosys. Environ, 204: 51-61.

[28] Témé, B., Breman H, Sissoko K. (1996). Intensification agricole au Sahel: Mythe ou Réalité? Rapport de Synthèse des Travaux du Colloque International, Wageningen.

[29] Uphoff, N. (2013). Agroecological innovations: increasing food production with participatory development. Routledge. Earthscan Pulications Ltd, London.

[30] Kang, B. T., Caveness, F. E., Tian, G., Kolawole, G. O. (1999). Longterm alley cropping with four hedgerow species on an Alfisol in southwestern Nigeria effect on crop performance, soil chemical properties and nematode population. Int J. Nutr. Cycl. Agroecosyst, 54: 145-155.

[31] Kwesiga, F., Akinnifesi, F., Mafongoya, P. (2003). Agroforestry research and development in southern Africa during the 1990s: Review and challenges ahead. Agroforestry Systems, 59: 173-186.

[32] Beedy, T. L., Snapp, S. S., Akinnifesi, F. K., Sileshi, G. W. (2010). Impact of Gliricidia sepium Intercropping on soil organic matter fraction in a maize-based cropping system. Int. J. Agric. Ecosys. Environ, 138: 139-146.

[33] Partey, S. T., Zougmoré, R. B., Ouédraogo, M., Campbell, B. M. (2018). Developing climate-smart agriculture to face climate variability in West Africa: Challenges and lessons learnt. Int. J. Cleaner Production, 187: 285-295.

[34] IUSS, Working Group WRB. (2015). World Reference Base for Soil Resources 2014, update 2015. International soil classification system for naming soils and creating legends for soil maps, World Soil Resources Reports. FAO, Rome.

[35] Sacande, M., Sanogo, S., Beentje, H. (2016). Guide d'identification des arbres du Mali. Royal BotanicGardens, Kew.

[36] Agroscope. (1996-2018). Referenzmethoden der Eidgenössischen landwirtschaftlichen Forschungsanstalten. Bodenuntersuchung zur Düngeberatung; Zürich-Reckenholz.

[37] Hansen, B. (1989). Determination of Nitrogen as Elementary N, an Alternative to Kjeldahl. Int J. Acta Agriculturae Scandinavica, 39: 113-118.

[38] Kang, B. T. (1997). Alley cropping-soil productivity and nutrient recycling. Int. J. For. Ecol. Manage, 91: 75-82.

[39] Vanlauwe, B., Aihou, K., Tossah, B. K., Diels, J., Sanginga, N., Merckx, R. (2005). Senna siamea trees recycle Ca from a Ca-rich subsoil and increase the topsoil $\mathrm{pH}$ in agroforestry systems in the West African derived savanna zone. Int. J. Plant Soil, 269: 285-296.

[40] Cobbina, J., Ata-Krah, A. N., Meregini, A. O., Duguma, B. (1990). Productivity of some browse plants on soils of southeastern Nigeria. Tropical Grasslands, 24(1): 41-45.

[41] Young, A. (1989). Agroforestry for soil conservation (2e éd). British Library Cataloguing in Publication Data, Wallingford.

[42] Mapa, R. B., Gunasena, H. P. M. (1995). Effect of alley cropping on soil aggregate stability of a tropical Alfisol. Int. J. Agroforest Syst, 32: 237-245.

[43] Jabbar, M. A., Reynolds, L., Larbi A., Smith, J. (1997). Nutritional and economic benefits of Leucaena and Gliricidia as feed supplements for small ruminants in humid West Africa. Int. J. Tropical Animal Health and Production, 29: 35-47.

[44] Diouf, A., Diop, T., Fall-Ndiaye, M., Gueye, M. (2008). Impact de la biomasse de Gliricidia sepium utilisée comme engrais vert sur la culture du mais (Zea mays) au Sénégal. Int. J. Sciences, 8(3): 10-17.

[45] Sileshi, G., Akinnifesi, F. K., Ajayi, O. C., Place, F. (2008). Meta-analysis of maize yield response to woody and herbaceous legumes in sub-Saharan Africa. Int. J. Plant Soil, 307: 1-19.

[46] Smethurst, P. J., Huth, N. I., Masikati, P., Sileshi, G. W., Akinnifesi, F. K., Wilson, J., Sinclair, F. (2017). Accurate crop yield predictions from modelling tree-crop interactions in gliricidia-maize agroforestry. Int. J. Agric. Syst, 155: 70-77.

[47] Kuyah, S., Whitney, C., Jonsson, M., Sileshi, G. W., Öborn, I., Muthuri, C. W., Luedeling, E. (2019). Agroforestry delivers a win-win solution for ecosystem services in sub-Saharan Africa. A meta-analysis. Agron. Sustain Dev, $39: 47$.

[48] Whittome, M. P. B., Spencer, D. S. C., Bayliss-Smith, T. (1995). IITA and ILCA on-farm alley farming research: Lessons for extension workers (éd.), Alley farming research and development.

[49] Adesina, A. A., Chianu, J. (2002). Determinants of farmers' adoption and adaptation of alley farming technology in Nigeria. Int. J. Agroforest Syst, 55: 99-112.

[50] Luedeling, E., Smethurst, P. J., Baudron, F., Bayala, J., Huth, N. I., van Noordwijk, M., Ong, C. K., Mulia, R., Lusiana, B., Muthuri, C., Sinclair, F. L. (2016). Field-scale modeling of tree-crop interactions: Challenges and development needs. Int. J. Agric. Syst., 142: 51-69.

[51] Banwart, S., Black, H., Cai, Z., Gicheru, P., Joosten, H., Victoria, R., Milne, E., Noellemeyer, E., Pascual, U., Nziguheba, G., 
Vargas, R., Bationo, A., Buschiazzo, D., de-Brogniez, D., Melillo, J., Richter, D., Termansen, M., van Noordwijk, M., Goverse, T., Ballabio, C., Bhattacharyya, T., Goldhaber, M., Nikolaidis, N., Zhao, Y., Funk, R., Duffy, C., Pan, G., la Scala, N., Gottschalk, P., Batjes, N., Six, J., van Wesemael, B., Stocking, M., Bampa, F., Bernoux, M., Feller, C., Lemanceau, P., Montanarella, L. (2014). Benefits of soil carbon: report on the outcomes of an international scientific committee on problems of the environment rapid assessment workshop. Int. J. Carbon Management, 5(2): 185-192.

[52] Bernoux, M., Chevallier, T. (2014). Carbon in dryland soils Multiple essential functions. CSFD/Agropolis International, Montpellier.

[53] Havlicek, E., Mitchell, E. A. D. (2014). Soils Supporting Biodiversity. In: Dighton J, Krumins J. (eds) Interactions in Soil: Promoting Plant Growth. Biodiversity, Community and Ecosystems. Int. J. Springer, Dordrecht, 1: 27-58.

[54] Brady, M. V., Hedlund, K., Cong, R. G., Hemerik, L., Hotes, S., Machado, S., Mattsson, L., Schulz, E., Thomsen, I. K. (2015). Valuing Supporting Soil Ecosystem Services in Agriculture: A Natural Capital Approach. Int. J. Agron, 107: 1809-1821.

[55] Milne, E., Banwart, S. A., Noellemeyer, E., Abson, D. J., Ballabio, C., Bampa, F., Bationo, A., Batjes, N., Bernoux, M., Bhattacharyya, T., Black, H., Buschiazzo, D. E., Cai, Z., Cerri, C. E., Cheng, K., Compagnone, C., Conant, R., Coutinho, H. L. C., de Brogniez, D., Balieiro, F. d. C., Duffy, C., Feller, C., Fidalgo, E. C. C., da Silva, C. F., Funk, R., Gaudig, G., Gicheru, P. T., Goldhaber, M., Gottschalk, P., Goulet, F., Goverse, T., Grathwohl, P., Joosten, H., Kamoni, P. T., Kihara, J., Krawczynski, R., La Scala, N., Lemanceau, P., Li, L., Li, Z., Lugato, E., Maron, P-A., Martius, C., Melillo, J., Montanarella, L., Nikolaidis, N., Nziguheba, G., Pan, G., Pascua, l U., Paustian, K., Piñeiro, G., Powlson, D., Quiroga, A., Richter, D., Sigwalt, A.,. Six, J., Smith, J., Smith, P., Stocking, M., Tanneberger, F., Termansen, M., van Noordwijk, M., van Wesemael, B., Vargas, R., Victoria, R. L., Waswa, B., Werner, D., Wichmann, S., Wichtmann, W., Zhang, X., Zhao, Y., Zheng, J., Zheng, J. (2015). Soil carbon, multiple benefits. Int. J. Environmental Development, 13: 33-38.

[56] Baveye, P. C.,Baveye, J., Gowdy, J. (2016). Soil “Ecosystem” Services and Natural Capital: Critical Appraisal of Research on Uncertain Ground. Int. J. Front. Environ. Sci, 4(41).

[57] FAO. (2017). Soil Organic Carbon: the hidden potential, Food and Agriculture Organization of the United Nations, Rome.

[58] Van der Wal, A., de Boer, W. (2017). Dinner in the dark: Illuminating drivers of soil organic matter decomposition. Int J. Soil Biology and Biochemistry, 105: 45-48.

[59] Koch, A., McBratney, A., Adams, M., Field, D., Hill, R., Crawford, J., Minasny, B., Lal, R., Abbott, L., O'Donnell, A., Angers, D., Baldock, J., Barbier, E., Binkley, D., Parton, W., Wall, D. H., Bird, M., Bouma, J., Chenu, C., Flora, C. B., Goulding, K., Grunwald, S., Hempel, J., Jastrow, J., Lehmann, J., Lorenz, K., Morgan, C. L., Rice, C.W., Whitehead, D., Young, I., Zimmermann, M. (2013). Soil Security: Int. J. Solving the Global Soil Crisis. Global Policy, 4: 434-441.

[60] McBratney, A., Field, D. J., Koch, A. (2014). The dimensions of soil security. Int. J. Geoderma., 213: 203-213.

[61] Vanlauwe, B., Bationo, A., Chianu, J., Giller, K. E., Merckx, R., Mokwunye, U., Ohiokpehai, O., Pypers, P., Tabo, R., Shepherd, K. D., Smaling, E. M. A., Woomer, P. L., Sanginga, N. (2010). Integrated soil fertility management-Operational definition and consequences for implementation and dissemination. Int. J. Agric, 39: 17-24.

[62] Vanlauwe, B., Kihara, J., Chivenge, P., Pypers, P., Coe, R., Six, J. (2011). Agronomic use efficiency of N fertilizer in maize-based systems in sub-Saharan Africa within the context of integrated soil fertility management. Int. J. Plant Soil, 339: 35-50.

[63] Fairhurst, T. (2015). Manuel de Gestion Intégrée de la Fertilité des Sols. Consortium Africain pour la Santé des Sols, Nairobi.

[64] Adekiya, A. O. (2018). Legume Mulch Materials and Poultry Manure Affect Soil Properties, and Growth and Fruit Yield of Tomato. Int. J. Agriculturae Conspectus Scientificus, 83 (2): 161-167.

[65] Akintan, C. I. (2019). Agronomic Performance of Maize (Zea mays L.) as influenced by Leaf Pruning Quality in a Cut and Carry Agroforestry System in Akure, Ondo State, Nigeria. Int. J. KIU of Humanities, 194: 199-208.

[66] Abbadie, L., Lata, J., Tavernier, V. (2000). Impact des graminées pérennes sur une ressource rare: Dans la jachère en Afrique tropicale. John Libbey Eurotext.

[67] Blondel, D. (1971). Contribution à la connaissance de la dynamique de l'azote minéral en sol sableux (dior) au Sénégal. Int. J. L'Agronomie Tropicale, 26(12): 1303-1333.

[68] Duguma, B., Tonye, J., Kanmegne, J., Manga, T., Enoch, T. (1994). Growth of ten multipurpose tree species on acid soils in Sangmelima, Cameroon. Int. J. Agroforest Syst, 27: 107-119.

[69] Giller, K., Cadisch, G., Ehaliotis, C., Adams, E., Sakala, W. D., Mafongaya, P. L. (1997). Building soil nitrogen capital in Africa (éd.). American Society of Agronomy and Soil Science Society of America, Replenishing Soil Fertility in Afrika. Soil Science Society of America, USA.

[70] Mafongaya, P. L., Kuntashula, E., Kwesiga, F., Chriwa, T., Chintu, R., Sileshi, G., Matibini, J. (2003). Leguminous agroforestry options for replenishing soil fertility in Southern Africa. Grain Legumes and Green Manures for Soil Fertility in Southern Africa: Taking Stock of Progress (éd.). Soil Fert Net and CIMMYT, Harare. 